Marcin Jędrysiak

Uniwersytet Wrocławski

Uniwersytet Ekonomiczny

\title{
Doktrynalne koncepcje reformy systemu opodatkowania lokalnego w Polsce
}

Mimo licznych dyskusji dotyczących reform ekonomicznych w Polsce stosunkowo słabo do społecznej świadomości dociera potrzeba zmian w podatkach lokalnych. Wydaje się, że ten temat jest obecny w dyskursie głównie za sprawą kontrowersyjnego pomysłu wprowadzenia podatku katastralnego (podatku od wartości nieruchomości) zamiast obecnego podatku od nieruchomości (opartego na powierzchni). Ostatnio, zawarta w projekcie Założeń Polityki Miejskiej do roku 2020 wzmianka o możliwości jego wprowadzenia zakończyła się burzliwą dyskusją i sprawiła, że ministerstwo rozwoju regionalnego musiało udzielać odpowiednich wyjaśnień ${ }^{1}$. Problem reformy opodatkowania lokalnego jest jednak jak najbardziej realny. Wśród samorządowców, prawników czy ekonomistów nie budzi kontrowersji to, że należy dokonać zmian w obecnym systemie podatkowym. Niekiedy mówi się zresztą o ogólnej potrzebie reformy finansów lokalnych - reforma administracyjna z 1998 r. nadała gminom nowe zadania i wydatki, niemniej nie zreformowano przy tym reformy systemu dochodów samorządu terytorialnego ${ }^{2}$. Problemy powstają także w obrębie systemu subwencji, doprowadzając do stałego konfliktu na linii państwo - jednostki samorządu terytorialnego. Niekiedy niegospodarnie działają same samorządy33. Przede wszystkim krytyka spada jednak na system podatków samorządowych.

1 Cf. <https://www.mir.gov.pl/aktualnosci/polityka_rozwoju/Strony/Nie_bedzie_nowego_podatku_08062012 .aspx> [dostęp: 30.03.2014]

2 E. Ruśkowski, Czy kryzys finansów lokalnych w Polsce? [w:] Księga Jubileuszowa profesora Marka Mazurkiewicza. Studia z dziedziny prawa finansowego, prawa konstytucyjnego i ochrony środowiska, red. R. Mastalski, Wrocław 2001, s. 170-172.

3 Ibidem, s. 172. 
Niniejsza praca stanowi próbę ukazania głównych założeń i kierunków zmian koncepcji reformy polskiego opodatkowania samorządowego wypracowanych przez polską doktrynę w ciągu ostatnich 20 latach.

\section{Typologia systemów opodatkowania lokalnego w Europie}

Zasadniczo w Europie można wyróżnić dwa główne modele opodatkowania lokalnego. Pierwszy z nich (funkcjonujący również w Polsce) zakłada oparcie dochodów lokalnych na podatku od nieruchomości. W 2009 r. dochody z podatku od nieruchomości stanowiły w Polsce 26,60 proc. wszystkich dochodów podatkowych gmin ${ }^{4}$. W $2012 \mathrm{r}$. współczynnik ten wzrósł do niemal 30 proc. ${ }^{5}$ Interesujące zestawienie relacji dochodów z tytułu podatku od nieruchomości względem PKB danego kraju przedstawił Paweł Felis ${ }^{6}$. W Polsce współczynnik ten wynosił w 2010 r. 1,2 proc. Jest to najbardziej rozpowszechniony w Europie model opodatkowania lokalnego. Drugi z nich oparty jest na podatku dochodowym od osób fizycznych i funkcjonuje w krajach skandynawskich, w Szwajcarii, a także w Chorwacji, gdzie działa jednak na zasadzie dodatku .

\section{Krytyka polskiego systemu opodatkowania lokalnego}

Polski system podatków lokalnych uważany jest za archaiczny ${ }^{8}$. Zasadniczo w sferze podatków budżet gminy zasilają środki z podatku od czynności cywilnoprawnych, podatku od spadków i darowizn, z podatków rozliczanych w formie karty podatkowej, z podatku od nieruchomości, podatku rolnego i leśnego oraz podatku od środków transportu. Wobec pierwszych czterech kategorii gmina nie ma jednak mocy stanowienia stawek czy zwolnień. Dysponuje w stosunku do nich władztwem

\footnotetext{
${ }^{4}$ M. Mazurek-Chwiejczak, Podatki lokalne w systemie finansowania samorządów - doświadczenia krajów $O E C D$, „Annales Universitatis Mariae Curie-Skłodowska. Sectio H, Oeconomia” 2012, Vol. 46, No. 3, s. 159.

5 Główny Urząd Statystyczny, Rocznik statystyczny Rzeczypospolitej Polskiej 2013, Warszawa 2013, s. 654.

${ }^{6}$ P. Felis Podatek od nieruchomości w Europie, „Infos” 2013, nr 1(138), s. 4.

7 P. Swianiewicz, J. Neneman, Koncepcje, warianty i konsekwencje wprowadzenia PIT-u komunalnego $w$ Polsce, Warszawa 2013, s. 9 [pdf, online]. Dostępny w internecie: <http://www.bgk.com.pl/storage/7150/Koncepcje_warianty_i_konsekwencje_wprowadzenia_PITu_komunalnego\%20_w_Polsce.pdf> [dostęp: 2.04.2014].

${ }^{8}$ L .Etel, Reforma opodatkowania nieruchomości w Polsce, Białystok 1998, s. 45 i nn.
} 
podatkowym w sensie szerokim ${ }^{9}$. Ograniczone władztwo podatkowe ma natomiast w stosunku do podatków: rolnego, leśnego, od nieruchomości oraz od środków transportu. Tylko dwa ostatnie reguluje ustawa o podatkach i opłatach lokalnych ${ }^{10}$. Zdaniem Leonarda Etela podział na podatki samorządowe w sensie wąskim i szerokim jest sztuczny i mylący, zaś sama ustawa o podatkach i opłatach lokalnych stanowi anachronizm. Postuluje zatem ujęcie wszystkich podatków lokalnych w ramach jednej regulacji, tworząc „autentyczny” system podatków komunalnych ${ }^{11}$. Kolejną propozycją jest połączenie jednym podatkiem - od nieruchomości - rozdzielonych trzema różnymi ustawami podatków: leśnego, rolnego i od nieruchomości ${ }^{12}$. Wpłynęłoby to pozytywnie na sam system prawa, eliminując wątpliwości interpretacyjne dotyczące zakresu przedmiotowego tych danin ${ }^{13}$. Problem pojawia się także $\mathrm{w}$ przypadku różnic $\mathrm{w}$ stawkach między tymi podatkami, które prowadzą w konsekwencji do unikania podatku od nieruchomości poprzez nabywanie przez podatników gruntów rolnych i leśnych.

Najbardziej krytykowany jest podatek od nieruchomości. Uważa się go za niedostosowany do standardów gospodarki rynkowej14. Zwraca się uwagę na jego niesprawiedliwość - właściciel nieruchomości w centrum Warszawy jest potencjalnie obciążony takim samym podatkiem jak właściciel podobnej nieruchomości w gminie wiejskiej na Podlasiu. Podkreśla się słabe spełnianie przez niego celów skarbowych i niewykorzystanie potencjału fiskalnego (niektórzy podatnicy byliby w stanie zapłacić większą kwotę podatku od nieruchomości). Z drugiej strony nie spełnia on też zdaniem niektórych autorów ${ }^{15}$ - funkcji pozafiskalnych. Ponadto brakuje wiarygodnej ewidencji, która pozwalałaby na określenie opodatkowanych nieruchomości i zgodne ze stanem rzeczywistym wyznaczenie ich powierzchni ${ }^{16}$.

\footnotetext{
9 T. Wołowiec, D. Reśko Obniżki stawek podatkowych do celów stymulacyjnych a założenia racjonalnej polityki podatkowej gminy, ,'Toruński Rocznik Podatkowy” 2012, s. 6.

${ }^{10}$ Ustawa z dnia 12 stycznia 1991 r. o podatkach i opłatach lokalnych, Dz.U. z 1991r. Nr 9 poz. 31 z późn. zm.

${ }^{11}$ L. Etel Podatek od nieruchomości. Komentarz, Warszawa 2012, s. 16-17.

${ }^{12}$ Idem, Reforma systemu opodatkowania nieruchomości. Raport $n r$ 15, Biuro Studiów i Ekspertyz Sejmu RP 1999.

${ }^{13}$ Ibidem.

${ }^{14}$ Idem, Reforma systemu..., s. 45 i nn.

${ }^{15}$ S. Gnat, Analiza wybranych skutków wprowadzenia podatku katastralnego, ,,Studia i Prace Wydziału Nauk Ekonomicznych i Zarządzania” 2009, nr 15, s. 52.

${ }^{16}$ Zdaniem T. Wołowca nie jest wiarygodna ewidencja gruntów i budynków, cf. T. Wołowiec, Reforma systemu opodatkowania nieruchomości w Polsce szansa pobudzenia rozwoju lokalnego i regionalnego samorządów terytorialnych, „Studia Regionalne i Lokalne” 2003, nr 4(14), s. 127.
} 
Wobec wyżej przedstawionych wad obecnego stanu prawnego pojawiła się seria koncepcji ukazujących możliwości, jakie stwarza reforma obecnego opodatkowania lokalnego oparta na doświadczeniach innych krajów Unii Europejskiej.

\section{„PIT komunalny” remedium na problemy systemu finansów komunalnych}

W Polsce pojawił się pomysł oparcia podatków lokalnych na podatku dochodowym od osób fizycznych. Stanowiłoby to całkowitą rewolucję w stosunku do obecnego stanu rzeczy. Pomysł ten wyszedł niezależnie z dwóch ośrodków: think-tanku Forum Odnowa ${ }^{17}$ oraz ekspertyzy Pawła Swianiewicza i Jarosława Nenemana dla Banku Gospodarstwa Krajowego Koncepcje, warianty i konsekwencje wprowadzenia PIT-u komunalnego $w$ Polsce $^{18}$. W raporcie tym wcześniejsze podniesienia tej kwestii przez Forum Od-nowa zostało zauważone - Swianiewicz i Neneman odnieśli się do zauważonych przez Forum szans i zagrożeń. Zaproponowane rozwiązanie miałoby zastąpić dotychczasowe wydzielenie udziału gmin $\mathrm{w}$ dochodach $\mathrm{z}$ podatku dochodowego od osób fizycznych.

Autorzy ekspertyzy widzą „lokalny PIT” (jak sami go określają) jako podatek liniowy, z gminą władną do samodzielnego ustalenia jego stawki, przy potencjalnym określeniu maksymalnej lub minimalnej stawki w ustawie. Autorzy krytycznie odnoszą się do stanowienia ulg i zwolnień przez gminę, twierdząc, że środki te są mało efektywne: uszczuplają dochody gmin oraz komplikują system podatkowy ${ }^{19}$. Podatek miałby być pobierany przez urzędy skarbowe. Jednakże komunalny podatek dochodowy od osób fizycznych zasiliłby nie tylko budżet gminy, ale także powiatów i województw, zachowując obecnie istniejące proporcje udziałów poszczególnych szczebli samorządu terytorialnego $\mathrm{w}$ dochodach $\mathrm{z}$ tego podatku. Baza podatkowa części rządowej $\mathrm{i}$ komunalnej byłaby identyczna, zaś ulgi odliczano by bądź to od obu części podatku, bądź

\footnotetext{
17 Forum Od-nowa, Rozszerzone rekomendacje do „Raportu o stanie samorzq̨dności terytorialnej w Polsce” [online], 19 marca 2013 [dostęp: 12.04.2014]. Dostępny w internecie: <http://www.forumodnowa.pl/index.php/teksty/19-samorzad-terytorialny/47-rekomendacje-doraportu-o-stanie-samorzadnosci-terytorialnej-w-polsceq>.

18 P. Swianiewicz, J. Neneman, Koncepcje, warianty i konsekwencje wprowadzenia PIT-u komunalnego w Polsce [pdf, online]. Dostępny w internecie: <http://www.bgk.com.pl/storage/7150/Koncepcje_warianty_i_konsekwencje_wprowadzenia_PIT-u_w komunalnego\%20_w_Polsce.pdf> [dostęp: 2.04.2014].

${ }^{19} \mathrm{~W}$ literaturze można też jednak napotkać stanowisko przeciwne oparte na badaniach, cf. np. A. Nalepka, A. Małkowska, Instrumenty gospodarki nieruchomościami w stymulowaniu rozwoju gospodarczego gmin na przykładzie województwa opolskiego, „Samorząd Terytorialny” 2013, nr 5, s. 68.
} 
tylko od części rządowej. Samorządy mogłyby określać odrębną kwotę wolną od podatku.

Autorzy zaproponowali cztery warianty „lokalnego PIT-u”. W pierwszym stawka wynosiłaby 4,416 proc., z przewidywaną kwotą wolną od podatku na poziomie $3090 \mathrm{zł}$. Ulgi podatkowe byłyby odpisywane od części rządowej, natomiast ulgi nieodliczone od części samorządowej zasiliłyby budżet centralny. Wariant drugi różniłby się jedynie zapisywaniem ulg na poczet samorządów, trzeci zakładałby opodatkowanie lokalnym podatkiem dochodowym od osób fizycznych wyłącznie osób osiągających wpływy podatkowe na poziomie drugiego progu podatkowego. Zmiana bazy podatkowej wymogłaby jednak podniesienie stawki podatku do poziomu 5,3815 proc. Wreszcie, wariant czwarty zakładałby potrącanie ulg zarówno z części rządowej, jak i samorządowej przy zwiększeniu stawki podatku do 5,0765 proc.

Propozycja przedstawiona przez Forum Od-nowa (wzorowana na rozwiązaniach skandynawskich ${ }^{20}$ ) także zakłada stawkę liniową podatku przy władztwie podatkowym gminy ograniczonym jedynie do ustalania stawki podatkowej. Baza podatkowa miałaby być $\mathrm{w}$ tym ujęciu jak najszersza (nie podano jednak szczegółów na ten temat). Ulgi miałyby być odliczane w pierwszej kolejności od dochodów z podatku dochodowego od osób fizycznych wpływających do budżetu centralnego, tak by możliwie najmniej obciążać jednostki samorządu terytorialnego (tylko gminy i powiaty - w odróżnieniu od raportu Banku Gospodarstwa Krajowego Forum postuluje, by podatek ten nie przynosił dochodów województwom). W przeciwieństwie do ekspertyzy Swianiewicza i Nenamana think-tank zakłada, by podatek obciążał najmniej zamożną część społeczeństwa, zostawiając państwu podatników o dochodach powyżej $40000 \mathrm{zł}$. Zdaniem autorów będzie to zachęcać do rozwijania polityki rynku pracy, inwestycji, a także przyciągnie podatników o mniejszych dochodach. Ponadto projekt Forum wkracza mocniej w sferę systemową: jego autorzy tworzą bowiem system gwarancji zapobiegających wewnątrzkrajowej konkurencji podatkowej: gminy nie miałyby prawa do zbyt gwałtownej podwyżki stawki (przewidziano nawet karanie ich obniżeniem kwoty subwencji), a co więcej, miałby zostać wprowadzony zakaz zbytniego różnicowania stawek między sąsiadującymi jednostkami samorządu terytorialnego.

\footnotetext{
${ }^{20}$ M. Cyrankiewicz, PIT komunalny - budowanie wspólnoty opartej na pieniądzach, „Rzeczpospolita” [online], 20 marca 2014 [dostęp: 23.03.2014], s. 2. Dostępny w internecie: <http://prawo.rp.pl/artykul/1095427.html>.
} 
Nieco nietypowym pomysłem jest określanie stawki podatku w uchwale budżetowej gminy - moim zdaniem może to być kontrowersyjne z punktu widzenia techniki ustawodawczej. Wreszcie, miałby powstać ogólnopolski system, w którym podatnik mógłby sprawdzić wysokość stawki podatku w każdej gminie.

Samorządowy podatek dochodowy od osób fizycznych miałby charakteryzować się szeregiem zalet: możliwością stworzenia lepszego powiązania między jakością usług i daniną, urealnieniem miejsca zapłaty „lokalnego PIT-u”, stabilnością źródła zasilania i jego lepszym rozkładem terytorialnym, co może wpłynąć na obniżenie kwoty subwencji ogólnej. Pobór lokalnego PIT-u wiąże się także - według raportu - z niskimi kosztami administracyjnymi, jego elastycznością i możliwością łatwego reagowania na sytuację ekonomiczną gminy dzięki manipulowaniu dopuszczalnymi stawkami przez administrację centralną, poszerzeniem zakresu instrumentów podatkowych gmin i stworzeniem takiego instrumentu w odniesieniu do powiatów, a także „wzrostem akceptacji dla systemu PIT”. Autorzy raportu bardzo mocno podkreślają rolę, jaką odgrywa świadomość podatników w łączeniu jakości usług zapewnianych przez gminę z poziomem jej dochodów. Motywacja wydaje się tutaj słowem-kluczem: mieszkańcy wreszcie wiedzieliby, ile wynosi ich wkład do sfery publicznej - do samorządów i budżetu centralnego. Mieszkańcy mieliby większe możliwości badania efektywności sfery budżetowej. Pozwalałoby to zdaniem autorów na wyeliminowanie fikcyjnych meldunków umożliwiających płacenie niższych podatków w gminach sąsiednich przy wykorzystywaniu infrastruktury gminy, w której podatnik naprawdę działa. Podatek ten miałby wręcz pełnić funkcję edukacyjną21. Zdaniem Swianiewcza i Nenemana głównym motywem, dla którego samorządowcy pragnęliby wprowadzenia „PIT-u lokalnego”, jest obawa przed ustanawianiem stawek i ulg przez władzę centralną.

To rozwiązanie nie jest pozbawione wad: problematyczne może okazać się w gminach ubogich, o dużym poziomie bezrobocia. Słabością projektu są też jego, nieco górnolotnie brzmiące, cele „umacniania tożsamości lokalnej” - bez tej otoczki może się wydawać, że projekt jest motywowany czystym fiskalizmem, co w konsekwencji może natrafić na znaczący opór społeczny. Zdaniem Swianiewicza i Nenemana trudności

\footnotetext{
${ }^{21} \mathrm{~A}$. Dambska, Lokalny PIT, wynagrodzenie radnych $i$ łączenie gmin - samorzq̨dowcy dyskutowali o reformach [online], 24 lutego 2014 [dostęp: 1.04.2014], s.1. Dostępny w internecie: <http://www.samorzad.lex.pl/czytaj/-/artykul/lokalny-pit-wynagrodzenie-radnych-i-laczenie-gmin-samorzadowcy-dyskutowali-o-reformach>.
} 
przysporzyłaby także kwestia domicylu podatkowego ${ }^{22}$. Z całą pewnością osobę fizyczną z racji jej mobilności jest trudniej zidentyfikować niż nieruchomość.

\section{Koncepcja lokalnego podatku obrotowego}

Kolejna propozycja reformy opodatkowania lokalnego, sformułowana przez Wojciecha Misiąga i Marcina Tomalaka,23 zakłada wprowadzenie lokalnego podatku obrotowego. Podatek od wartości sprzedaży towarów i usług konsumpcyjnych byłby dochodem własnym gminy lub województwa. Podatek ten zasilałby budżet jednostki samorządu terytorialnego, w której sprzedaż nastąpiła, w przypadku zaś wysyłkowej - tej, w której sprzedawca posiadałby filię, oddział lub siedzibę.

Gmina dysponowałaby szerokim zakresem władztwa podatkowego, będąc upoważnioną do ustalania stawki podatkowej (w granicach określonych ustawą) oraz stanowienia ulg i zwolnień. Dochody z tego podatku mogłyby zastąpić udziały gminy lub województwa w dochodach z podatków dochodowych.

Lokalny podatek obrotowy stosuje się w wielu krajach pozaeuropejskich (np. w Stanach Zjednoczonych Ameryki, w Japonii gminom jest przekazywana część dochodów z akcyzy). Niemniej jednak często ten system uznaje się za archaiczny i mało wydajny ${ }^{24}$. Wątpliwości nasuwa też dublowanie funkcjonujących już podatków obrotowych: od towarów i usług oraz podatku od czynności cywilnoprawnych (będącego przecież dochodem gminy). Skoro bowiem podatki obrotowe są w ramach Unii Europejskiej harmonizowane, tak by nie utrudniać swobodnego przepływu towarów i usług w ramach wspólnego rynku, to pytanie, jakie należałoby postawić brzmi: czy wprowadzenie lokalnego podatku obrotowego, różnicującego sytuację sprzedawcy w każdej gminie, nie zakłóciłoby konkurencji w ramach jednego tylko państwa? Mogłoby to doprowadzić do bardzo daleko idącej konkurencji podatkowej, której skutki nie musiałyby być wcale korzystne.

\footnotetext{
${ }^{22}$ P. Swianiewicz, J. Neneman, op. cit. s. 27-28.

${ }^{23}$ W. Misiąg, M. Tomalak Zasady podziatu środków publicznych między województwa. Rekomendacje dla polityki regionalnej [pdf, online]. Dostępny w internecie: <https://www.mir.gov.pl/rozwoj_regionalny/Polityka_regionalna/KSRR_2010_2020/Ekspertyzy/Documents/Mi siag_Tomalak_Zasady_podzialu_srodkow_usprawnienie_planowania_wieloletniego_170810.pdf> [dostęp: 10.04.2014].

${ }^{24}$ M. Mazurek-Chwiejczak, op. cit., s. 161.
} 


\section{Pomysł reformy podatku od nieruchomości. Reforma przez wydzielenie stref}

Rozwiązania oparte na podatku dochodowym od osób fizycznych oraz wprowadzeniu lokalnego podatku obrotowego nie zdobyły dużej popularności i literatura na ten temat jest raczej uboga. Dużo więcej uwagi poświęcono reformie najważniejszego podatku lokalnego - podatku od nieruchomości. Obecny archaiczny system znajduje podstawę w wywodzącej się jeszcze z lat 70. ustawy o niektórych podatkach i opłatach terenowych. Przedmiotem opodatkowania dla gruntów i budynków jest powierzchnia ${ }^{25}$ (budowle opodatkowane są od ich wartości). W większości krajów Europy Zachodniej dominuje natomiast wspomniany już podatek katastralny (jako ostatnia przyjęła ten system Irlandia, w której podatek katastralny funkcjonuje od 1 stycznia 2013 r.) ${ }^{26}$, liczony od wartości nieruchomości. Na Węgrzech oraz w Rumunii wprowadzono ponadto system mieszany, łączący cechy systemu powierzchniowego oraz katastralnego. System powierzchniowy funkcjonuje $\mathrm{w}$ Czechach (gdzie od lat oczekuje się wprowadzenia katastru ${ }^{27}$ ) oraz na Słowacji, jednak w porównaniu z Polską podatki czeskie i słowackie wykazują większy stopień zaawansowania. Opierają się bowiem na tzw. strefowaniu: jedna stawka podatku jest w zależności od wielkości danej gminy i jej roli (np. jako stolicy kraju, jednostki administracyjnej) mnożona przez odpowiednią liczbę. Podatnicy w najmniejszych gminach płacą jednokrotność podatku, w większych płacą jej kilkukrotność, w Pradze stawkę podatku mnoży się zaś przez 4,528.

Kolejnym pomysłem usunięcia niektórych wad obecnego podatku od nieruchomości jest zainspirowany przykładem czeskim oraz słowackim projekt Unii Metropolii Polskich w sprawie koniecznej sanacji systemu finansów samorządowych przedstawiony po raz pierwszy 23 kwietnia $2013 \mathrm{r}^{29} \mathrm{~W}$ projekcie tym nie ma słowa o

${ }^{25}$ L .Etel Co trzeba zmienić $w$ podatkach $i$ opłatach lokalnych [w:] Prawo finansowe $w$ warunkach członkostwa Polski w Unii Europejskiej. Księga jubileuszowa poświęcona profesor Wandzie Wójtowicz, red. A. Pomorska, P. Smoleń, J. Stelmasik, A. Gorgola, Lublin 2011, s. 87.

26 P. Wiśniewski, Podatek katastralny, „Nieruchomości i Prawo” 2013, nr 2-3, s. 23.

${ }^{27}$ P. Mrkyvka, Podatek od nieruchomości w Republice Czeskiej [w:] Europejskie systemy opodatkowania nieruchomości, red. L. Etel, Warszawa 2003, s. 117.

28 J. Krzemiński, Samorzq̨dy przygotowujq reformę podatku od nieruchomości [online], 30 października 2012 [dostęp: 10.04.2014]. Dostępny w internecie: <http://www.obserwatorfinansowy.pl/forma/rotator/samorzady-przygotowuja-reforme-podatku-odnieruchomosci/>.

29 Stanowisko Unii Metropolii Polskich z 23.IV.2013 roku w sprawie koniecznej sanacji systemu finansów samorzqdowych [pdf, online], 24 kwietnia 2013 [dostęp: 10.04.2014], s. 1-2. Dostępny w internecie: <http://www.metropolie.pl/wp-content/uploads/2014/03/stanowisko-finansowe-UMP-z-24-IV2013.pdf $>$. 
katastrze, natomiast zaproponowano uelastycznienie podatków lokalnych polegające na tym, że stawki byłyby zależne od wskaźnika PKB per capita w rejonie NUTS-3 (odpowiadającemu gminie). Takie określenie podatków pozwalałoby na manipulowanie jego stawką w zależności od lokalizacji. Projekt zakładał także kilka zmian o charakterze mniej systemowym, m.in. wprowadzenie możliwości nakładania większych stawek podatku od nieruchomości na sklepy wielkopowierzchniowe, dyskonty oraz galerie handlowe oraz wprowadzenie podatku od reklam. Ponadto standardowo postuluje się zastąpienie dotychczasowych trzech podatków (rolnego, leśnego i od nieruchomości) jednym wspólnym podatkiem od nieruchomości oraz likwidację zwolnień ustawowych.

Precyzyjna koncepcja reformy została przedstawiona przez Pawła Swianiewicza, Jarosława Nenemana oraz Julitę Łukomską ${ }^{30}$. Przewidziano system, w którym stawka podatku zależałaby od dochodu PKB na mieszkańca w danej gminie, modyfikowaną dodatkowo przez rolę danej gminy jako stolicy województwa lub przez status gminy o szczególnych wartościach turystycznych ${ }^{31}$. Mnożnik stawki wzrastałby do poziomu 2 dla nieruchomości komercyjnych i 3 dla niekomercyjnych. W ekspertyzie sformułowano dwa kolejne warianty, różniące się jedynie szybkością przyrostu stawki dla celów komercyjnych oraz niekomercyjnych. Ponadto znalazł się w niej opis wariantu opartego na rozwiązaniach czeskich. Słusznie jednak autorzy zauważyli, że w Polsce byłby on praktycznie niemożliwy do wprowadzenia ze względu chociażby na inny model gminy w obu krajach (w Czechach gminę tworzy jedna miejscowość). Nie zawsze też istnieje korelacja między liczbą mieszkańców a bogactwem danej gminy, co mogłoby prowadzić do niesprawiedliwego traktowania niektórych dużych, lecz biednych gmin. Niemniej warto zwrócić uwagę na pomysł oparcia się na czeskich i słowackich wzorcach.

\section{Podatek katastralny}

Najbardziej znaną koncepcją reformy podatków lokalnych jest wprowadzenie podatku katastralnego. Czołowym orędownikiem wprowadzenia tego podatku wydaje się Leonard Etel, który już w 1998 r. przedstawił dorobek polskiej myśli w tym zakresie ${ }^{32}$.

\footnotetext{
${ }^{30}$ P. Swianiewicz, J. Neneman, J. Łukomska, Koncepcje przekształceń podatku od nieruchomości, „,Finanse komunalne" 2013, nr 7-8.

${ }^{31}$ Ibidem, s. 34.
}

${ }^{32}$ L .Etel Reforma opodatkowania nieruchomości w Polsce, Białystok 1998. 
Natomiast pomysł wprowadzenia katastru sięga roku 199433. Reforma miałaby odbywać się w kilku fazach, trwać długo i wiele kosztować. Zdaniem Etela powinna się zacząć od ujednolicenia podatków lokalnych: rolnego, leśnego i od nieruchomości - ich elementów konstrukcyjnych oraz rozmiarów stawek przy zwiększeniu władztwa podatkowego gminy $\mathrm{w}$ podatkach rolnym i leśnym. Proces ten miałby zmniejszyć obawy oraz opór społeczny przeciwko wprowadzaniu podatku katastralnego. Etap drugi to zinstytucjonalizowanie wiarygodnego i kompletnego systemu ewidencji nieruchomości. Trwałby najdłużej, co wynika z pracochłonności związanej z wprowadzeniem katastru. Potrzeba bowiem czasu oraz dużych środków pieniężnych do wykonania wyceny wszystkich nieruchomości w Polsce. Taka ewidencja musiałaby ponadto zawierać np. dane o powierzchni nieruchomości, jej granicach, właścicielach czy ograniczeniach ich praw (służebności czy hipoteki). Dopiero ostatni etap stanowiłby rzeczywiste wprowadzenie podatku liczonego od powierzchni nieruchomości.

Leonard Etel w przedłożonym już w 1994 r. projekcie podatku proponuje zmiany, które dotyczyłyby przede wszystkim przedmiotu opodatkowania, przy pozostawieniu obecnej regulacji co do podmiotu. Wartość nieruchomości byłaby wyznaczona według jednej z opisanych w ustawie metod: rynkowej, czynszowej (dla nieruchomości będących przedmiotem najmu) lub bezpośredniej (dla nieruchomości unikatowych). O wartości nieruchomości podatnik byłby informowany decyzją, od której mógłby się również odwołać. Stawki podatku miałyby być określane przez radę gminy w granicach określonych ustawą i byłyby oznaczone jako procent wartości nieruchomości $\mathrm{z}$ uwzględnieniem celu przeznaczenia nieruchomości. Ponadto przewidziano pozostawienie ustawowych ulg podatkowych. Tylko niewielkie zmiany miałyby dosięgnąć poboru podatku: przez pierwsze lata wszystkim podmiotom podatek byłby wymierzany w drodze decyzji, dopiero w późniejszych latach zobowiązano by część podmiotów do samodzielnych deklaracji podatków.

Kompleksowość systemu katastralnego dobrze oddaje to, że do jego wprowadzenia przewidywano potrzebę uchwalenia kilku aktów prawnych: ustawy o podatku od nieruchomości, ustawy o warunkach wcześniejszego wprowadzenia podatku od nieruchomości, prawa o katastrze nieruchomości, ustawy o obligatoryjnych związkach gmin i miastach wydzielonych oraz o samorządowych urzędach podatków

${ }^{33}$ Zawiera ją druk Szczegółowe założenia projektu ustawy o katastrze nieruchomości oraz o opodatkowaniu nieruchomości opracowany przez zespół ds. reformy systemu podatkowego, cf. ibidem, s. 224. 
lokalnych i katastru oraz ustawy o Centralnym Urzędzie Katastru, Geodezji i Kartografii ${ }^{34}$.

Problemy stojące na drodze do reformy opodatkowania mają przyczyny polityczne: podatki lokalne zasilają budżet gmin, a więc rządzący nie są zainteresowani jakąkolwiek zmianą antagonizującą wyborców, z której niewielkie korzyści miałby budżet. Podatek katastralny dotyczyłby nieruchomości rolnych, leśnych oraz pozostałych. Stawki podatku od dwóch pierwszych kategorii stopniowo miałyby być przystosowane do poziomu podatku od nieruchomości. Podmiotem podatku byłby władający nieruchomością. Zdaniem pomysłodawców reformy przedmiot opodatkowania powinien być szeroki i oparty na definicji z prawa budowlanego. Podobnie jak $\mathrm{w}$ obecnym stanie prawnym, projekt ten zakłada istnienie stawki maksymalnej określonej w ustawie, przy pozostawieniu gminie samodzielności w decydowaniu o jej wysokości w tych granicach. Katalog ustawowych ulg i zwolnień miałby być także bardzo ograniczony. Natomiast pobór podatku odbywałby się na obecnych zasadach ${ }^{35}$.

Wprowadzenie podatku katastralnego natrafia na liczne trudności. Pierwszą z nich, już zasygnalizowaną, jest konieczność wprowadzenia systemu katastralnego obejmującego oszacowanie wartości każdej nieruchomości, a także stworzenie map i tabel taksacyjnych. Koszty takiego systemu mogłyby wynosić - zdaniem niektórych badaczy - nawet 2 mld zł. ${ }^{36}$ Co więcej, potrzebna byłaby wiarygodna procedura wyceny nieruchomości. Jednakże prawdziwym problemem jest opór społeczny. Wprowadzenie podatku od wartości nieruchomości nieuchronnie doprowadziłoby do zwiększenia obciążeń podatkowych. Teoretycznie zyskałyby na tym gminy, a system opodatkowania nieruchomości stałby się bardziej sprawiedliwy. Obciążenia podatkowe wzrosłyby jednak kilku, a może nawet kilkunastokrotnie ${ }^{37}$. Korelacja między wartością

\footnotetext{
34 Ibidem, s. 226-227. Przytaczane przez Etela poglądy należy datować na wiele lat przed wyrokiem Trybunału Konstytucyjnego z 13 września 2011 r., sygn. akt P 33/09. Stąd niektóre z nich w świetle wyroku zdają się zdezaktualizowane.

35 Ibidem, s. 248-265.

36 Ł. Zalewski, Polskich samorzq̨dów nie stać na wprowadzenie podatku katastralnego od wartości nieruchomości, „Gazeta Prawna" [online], 28 sierpnia 2012 [dostęp: 20.03.2014]. Dostępny w internecie: <http://podatki.gazetaprawna.pl/artykuly/642697,polskich_samorzadow_nie_stac_na_wprowadzenie_po datku_katastralnego_od_wartosci_nieruchomosci.html>.

37 Przykładowo, średnia cena używanej nieruchomości mieszkalnej we Wrocławiu wynosiła w 2013 r. 5 742 zł za m² (dane za październik 2013 r. [online, dostęp: 20.04.2014]: <http://halo.domy.pl/raport-zrynku-nieruchomosci-pazdziernik-2013>). Stawka podatku od nieruchomości dla budynków mieszkalnych wynosiła w tym roku 0,73 zł za m² powierzchni użytkowej (cf. uchwała $\mathrm{nr}$ XXXV/757/12
} 
nieruchomości a poziomem życia w Polsce nie musi być też wcale oczywista (zwłaszcza na terenach poniemieckich). Taki podatek uczyniłby wiele dużych miejscowości nieatrakcyjnymi pod względem inwestycyjnym. I chociaż istnieją analizy pokazujące, że wprowadzenie katastru nie byłoby aż tak szkodliwe, jak się czasem wydaje, nie zostały one jednak przeprowadzone dla dużych miast, takich jak Kraków czy Warszawa, których mieszkańcy niewątpliwie straciliby na tym rozwiązaniu ${ }^{38}$.

Wprowadzenie podatku katastralnego nie jest dobrym pomysłem ze względu na jego kosztochłonność i niedostosowanie do specyfiki polskiego rynku nieruchomości39. Nie można bowiem abstrahować od ekonomicznego kontekstu danego rozwiązania prawnego. Z pewnością koszty podwyższenia podatku zostałyby przeniesione na najemców czy dzierżawców. Podatek katastralny stanowiłby też dodatkowy koszt dla osób spłacających kredyty hipoteczne. Sprawiedliwość nie zawiera się tylko w ramach przepisów prawnych oraz tego, jak dane podmioty zostały potraktowane na gruncie ustawy podatkowej, ale także w tym, jakie dałaby rezultaty pod względem gospodarczym. Nie są jasne powody, dla których stopniowe wprowadzenie podatku katastralnego w przypadku tak znaczącego wzrostu obciążeń podatkowych miałoby w jakikolwiek sposób ograniczyć opór społeczny wobec nawet kilkunastokrotnego wzrostu zobowiązania podatkowego. Mogą być uzasadnione obawy wyrażone chociażby w interpelacji nr $5496^{40}$ skierowanej przez posłankę Izabelę Kloc do minister Elżbiety Bieńkowskiej, w której podniesiono m.in. problem samotnych lokatorów mieszkań w centrum miasta oraz ewentualnej segregacji społecznej w gminach miejskich. Podatek katastralny jest tutaj wręcz nazywany haraczem. Interpelacja ta dosyć dobrze oddaje

Rady Miejskiej Wrocławia z dnia 29 listopada 2012 r. w sprawie określenia wysokości stawek podatku od nieruchomości). Teoretycznie więc za mieszkanie (nieprzeznaczone do prowadzenia działalności gospodarczej) o powierzchni użytkowej $70 \mathrm{~m}^{2}$ podatnik zapłaciłby 51,1 zł podatku. Cena rynkowa tej nieruchomości przy przyjęciu średniej ceny z października 2013 r. wynosiłaby 401940 zł. Stawka podatku od wartości nieruchomości o wysokości 0,25\% (taka jak w Irlandii) skutkowałaby wzrostem obciążenia podatkowego niemal dwudziestokrotnie, osiągając 1004,85 zł! Nawet wprowadzenie stawki dziesięciokrotnie niższej doprowadziłoby do dwukrotnego wzrostu zobowiązania podatkowego. Oczywiście, niniejszy przykład został wyprowadzony za pomocą uśrednionych danych dostarczonych przez analityków rynkowych, nie prezentuje stawki dla wartości nieruchomości określonej przez rzeczoznawcę majątkowego dla całkowicie losowo wybranej powierzchni i dla jednej z proponowanych stawek podatku (Np. S. Gnat przeprowadza badania dla stawek 0,1\%, 0,25\%, 0,5\%, 0,75\%, 1\% i 2,5\%, cf. S. Gnat, op. cit., s. 56-57), nie uwzględniając wielu czynników zewnętrznych. Daje on jednak pewien pogląd na to, jak znacząco może wzrosnąć wysokość zobowiązania podatkowego.

${ }^{38}$ S. Gnat w przytaczanej pracy przeprowadza analizę dla gminy Kołbaskowo.

${ }^{39}$ Być może przy badaniu perspektyw wprowadzenia systemu katastralnego warto byłoby dokonać analizy problemów występujących $\mathrm{w}$ związku z aktualizacją opłaty za użytkowanie wieczyste - również daniny publicznej opartej na wartości nieruchomości.

40 Interpelacja $\mathrm{nr} 5496 \mathrm{w}$ sprawie propozycji wprowadzenia podatku katastralnego w dokumencie Założenia Krajowej Polityki Miejskiej do 2020 roku. 
nastroje tak wyborców, jak i przedsiębiorców. Opór społeczny i polityczny wobec „haraczu” katastralnego wydaje się w chwili obecnej nie do przezwyciężenia ${ }^{41}$.

\section{Wnioski i perspektywy}

W ostatnich latach sformułowano cztery koncepcje reformy opodatkowania lokalnego. Bardzo małe szanse powodzenia ma wprowadzenie lokalnego podatku obrotowego, który rzadko uznaje się dobrym podatkiem lokalnym. Nie spełnia bowiem niektórych założeń dobrego podatku samorządowego ${ }^{42}$, m.in. nie jest wystarczająco jednoznaczny terytorialnie (sprzedaż i usługi mogą dotyczyć przecież obszaru większego niż gmina). Co więcej, można mieć wątpliwości co do związku przestrzennego między prowadzeniem przedsiębiorstwa a daną gminą: przedsiębiorca nie musi przecież prowadzić działalności gospodarczej w gminie, w której znajduje się centrum jego interesów osobistych i z której usług ma zamiar korzystać. Również trwałość tego związku nie jest oczywista. Niektóre usługi mogą być przecież dostarczane na terenie różnych gmin. Podatki obrotowe są też narażone na wahania koniunktury sprawiające, że stają się one mało stabilnymi źródłami dochodu. Podatki obrotowe są dużo bardziej skomplikowanym instrumentem niż dochodowe czy majątkowe. Podatek katastralny z kolei w polskich warunkach może okazać się niedostosowany do realiów ekonomicznych oraz szkodliwy społecznie, natrafia ponadto na zbyt duży opór społeczeństwa. Oprócz tego należy krytycznie podejść do kosztochłonności tego rozwiązania.

Natomiast największe szanse powodzenia mają próby „strefowania” lub wprowadzenia lokalnego PIT-u, przy czym pierwsze rozwiązanie ze względu na systemową prostotę i to, że system ten został już przetestowany (z różnym skutkiem) w

\footnotetext{
41 PAP, Posłowie PiS alarmujq: Rzq̨d chce wprowadzić podatek katastralny, „Polska” [online], 5 czerwca 2012 [dostęp: 14.04.2014]. Dostępny w internecie: <http://www.polskatimes.pl/artykul/590961,poslowie-pis-alarmuja-rzad-chce-wprowadzic-podatekkatastralny,id,t.html>. Przeciw podatkowi katastralnemu wypowiadały się także Izby Przemysłowe, np. A. Czernomord, Podatek katastralny - czy należy się go obawiać? [pdf, online]. Dostępny w internecie: <http://www.izbapruszcz.pl/pliki/podatek_katastralny.pdf> [dostęp: 15.05.2014]. Cf. także J. Ryba, Podatek katastrofalny, czyli „rodzina na bruku” [online], 26 czerwca 2012 [dostęp: 15.05.2014]. Dostępny w internecie: <http://www.bankier.pl/wiadomosc/Podatek-katastrofalny-czyli-Rodzina-Na-Bruku2577905.html>. Kilka powyższych przykładów pokazuje zgodny sprzeciw opozycji politycznej, ekspertów oraz przedsiębiorców wobec prób wprowadzenia tego podatku.

42 Cechy dobrego podatku samorządowego zostały zwarte chociażby we wspomnianej ekspertyzie dotyczącej wprowadzenia lokalnego podatku dochodowego od osób fizycznych, cf. P. Swianiewicz, J. Neneman, op. cit., s. 14-16.
} 
warunkach czeskich oraz słowackich (a zatem w dwóch bliskich Polsce krajach postkomunistycznych), wydaje się, że natrafia na mniejsze trudności. Taka reforma nie potrzebowałaby wprowadzania rewolucyjnych dla systemu zmian ani nie powodowałaby radykalnego wzrostu stawki podatkowej (nawet w najbogatszych miastach), przy okazji realizując postulaty większej elastyczności oraz sprawiedliwości podatku od nieruchomości.

Niemniej jednak w wielu projektach widać zbieżność niektórych postulatów, takich jak: przyznanie gminom większego zakresu władztwa podatkowego czy stworzenia powiązania między poziomem rozwoju gminy a wysokością zobowiązania podatkowego, zastąpienie trzech podatków (rolnego, leśnego i od nieruchomości) jednym podatkiem od nieruchomości. Wszelkie zmiany, niezależnie od ich oceny prawnej czy ekonomicznej, natrafiają na ten sam problem: do ich przeprowadzenia potrzeba określonej siły politycznej.

System finansów państwowych i samorządowych cechują natomiast mocne wzajemne powiązania sprawiające, że za jedną reformą będą musiały iść następne: $w$ innych podatkach, w systemie finansowania czy podziału dochodów z podatków dochodowych (jeśli dochody samorządów się zwiększą, w interesie budżetu centralnego będzie np. zmniejszenie kwoty subwencji ogólnej czy udziału gmin w dochodach podatkowych). Pozostaje postawić pytanie, czy jakiemuś ośrodkowi władzy starczy sił i woli politycznej, by którąś z przedstawionych propozycji reform przeprowadzić. Przegląd ten pokazuje jednak kierunek zmian, w którym powinna iść reforma polskich podatków lokalnych. 